\title{
The Effect of Anaerobiosis and Bile Salts on the Growth and Toxin Production by Vibrio cholerae
}

\author{
By PRABHAVATHI B. FERNANDES* AND H. L. SMITH, JR \\ Department of Microbiology, Thomas Jefferson University, \\ Philadelphia 19107, U.S.A.
}

(Received I2 March 1976; revised 22 June 1976)

\begin{abstract}
SUMMARY
Environmental conditions which might be present in the human intestinal lumen, such as anaerobiosis, a temperature of $37^{\circ} \mathrm{C}$ and the presence of bile salts, were examined for their effects on the growth and toxin production by Vibrio cholerae strains 569B and $\mathrm{BI} 307$ in Syncase and in peptone water media. Using aerobic conditions at $30^{\circ} \mathrm{C}$, which are commonly used for enterotoxin production, toxin $\left(5 \mu \mathrm{g} \mathrm{ml}^{-1}\right)$ and pleomorphic cells were detected during the exponential phase of the growth cycle. When the incubation temperature was raised to $37^{\circ} \mathrm{C}$, no toxin $\left(<0^{\circ} \mathrm{I} \mu \mathrm{g} \mathrm{ml}^{-1}\right)$ and no pleomorphic forms were found. In cultures incubated anaerobically at 30 or $37^{\circ} \mathrm{C}$, the organisms grew poorly, forming pleomorphic cells which lysed after the cultures reached a maximum turbidity at $640 \mathrm{~nm}$ of $\mathrm{I} \cdot 45$ at I2 $\mathrm{h}$. Toxin $\left(2.5 \mu \mathrm{g} \mathrm{ml}^{-1}\right)$ was present at $\mathrm{I} 2,24$ and $48 \mathrm{~h}$. When $0 . \mathrm{I} \%$ sodium deoxycholate was incorporated into the culture medium, growth was inhibited under aerobic conditions at 30 and $37^{\circ} \mathrm{C}$. At $30^{\circ} \mathrm{C}$ under aerobic conditions and at $37^{\circ} \mathrm{C}$ under anaerobic conditions, the toxin yield was not significantly affected by the presence of sodium deoxycholate; but at $37^{\circ} \mathrm{C}$ under aerobic conditions, sodium deoxycholate caused an increase in the toxin yield $\left(5 \mu \mathrm{g} \mathrm{ml}^{-1}\right)$ due to the release of cell-bound toxin.
\end{abstract}

\section{INTRODUCTION}

During the disease cholera, large numbers of Vibrio cholerae are present in the small gut (Gorbach et al., 1970). Freter (1969) showed that only those organisms adhering to the intestinal epithelial cells are necessary to produce the disease. At this site, the degree of oxygenation is probably less than that in the type of well-aerated culture vessel generally used in studies on toxin production (Burrows \& Kaur, 1974). Although $V$. cholerae grows best in vitro under aerobic conditions, von Hirsch (1926) and Banerjee (1939) have demonstrated that it can grow anaerobically. Linton, Mitra \& Seal (1936) found that the protein breakdown in cultures grown anaerobically was less than that in cultures incubated under aerobic conditions. However, enterotoxin production under anaerobic conditions has not been well characterized.

The vibrios in the intestine are at $37^{\circ} \mathrm{C}$ which is the optimal temperature for growth under aerobic conditions (Pollitzer, I959). However, toxin yield at this temperature in vitro under aerobic conditions is less than that in cultures incubated at 25 to $30^{\circ} \mathrm{C}$ (Craig, I966; Richardson, 1969).

In the small intestine, $V$. cholerae must grow in an environment which contains bile. Vibrios grow in the presence of bile salts - such salts are incorporated into selective media

* Present address: Institute for Cancer Research, Burholme Avenue, Fox Chase, Philadelphia I9III, U.S.A. 
used for their isolation (Pollitzer, 1959) - but they are unable to deconjugate bile salts (Norman \& Grubb, 1955). Freter (1972) found that rabbit bile enhanced the adsorption of vibrios to the intestinal mucosa. Other investigators (De, Ghosh \& Chandra, 1962) were unable to demonstrate toxin production in cultures of $V$. cholerae grown in medium containing $0.5 \%$ bile salts (Difco). This investigation was undertaken to determine the effects of anaerobiosis, a temperature of $37^{\circ} \mathrm{C}$ and bile salts on the growth and toxin production in vitro by $V$. cholerae.

\section{METHODS}

Bacterial strains. Freeze-dried cultures of $V$. cholerae strains 5698 and BI 307 were obtained from Dr John C. Feeley, N.I.H., Bethesda, Maryland, U.S.A. The rehydrated cultures were passaged twice in rabbit intestinal loops and re-isolated on Brain-Heart Infusion agar (Difco). These were lyophilized and stored at $4{ }^{\circ} \mathrm{C}$.

Media. Syncase (Finkelstein et al., I966) and peptone water (Burrows \& Kaur, 1974) were used. In preliminary experiments, the $\mathrm{pH}$ of these media fell to approximately 6.0 when kept under anaerobic conditions. The media were therefore buffered with $0.025 \mathrm{M}-$ Tris and the $\mathrm{pH}$ was adjusted to $8 \cdot 0$. The Tris-buffered media were prepared in large batches and distributed in $150 \mathrm{ml}$ portions to $250 \mathrm{ml}$ Erlenmeyer flasks fitted with cotton plugs. For anaerobic growth, all media were prereduced by keeping them for $\mathrm{I} 8 \mathrm{~h}$ in the anaerobic chamber described below. Media containing bile salts were prepared by adding I g (2.2 mM) sodium deoxycholate (Fisher Scientific Co., King of Prussia, Pennsylvania, U.S.A.), I g (2.5 mM) sodium glycocholate (Calbiochem) or I g Brij-38 (Calbiochem) to I 1 Syncase or peptone water. Sodium glycocholate and sodium deoxycholate were both found to be pure when tested by thin-layer chromatography (Hofmann, 1962).

Growth conditions. Aerobic incubation was carried out at 30 or $37^{\circ} \mathrm{C}$ in a water-bath shaker operated at $180 \mathrm{rev} . \mathrm{min}^{-1}$ over a $5 \mathrm{~cm}$ diam. Anaerobiosis was achieved by two methods. A flexible fibre chamber similar to that described by Aranki \& Freter (1972) was used for stationary cultures with an atmosphere in the chamber of $5 \% \mathrm{CO}_{2}, 88 \% \mathrm{~N}_{2}$ and $7 \% \mathrm{H}_{2}$. The oxygen content was approximately 5 p.p.m. as determined by an oxygen analyser (Lockwood and McLorie, Horsham, Pennsylvania, U.S.A.). The oxidationreduction potential was at least $-125 \mathrm{mV}$ as indicated by the reduction of indigo carmine. The relative humidity was 45 to $60 \%$ and the temperature was $37^{\circ} \mathrm{C}$.

Cultures to be shaken under anaerobic conditions were inoculated into media prereduced in the chamber. The filasks were placed in Gaspak jars (BBL) in the chamber, and then the jars were removed and placed in water-bath shakers at 30 or $37^{\circ} \mathrm{C}$.

Inocula. A fresh vial of lyophilized stock culture was used for each experiment. The culture was reconstituted by adding $\mathrm{I} \mathrm{ml}$ of the medium to be used. A loopful of this was inoculated into $5 \mathrm{ml}$ culture medium and incubated under aerobic or anaerobic conditions at 30 or $37^{\circ} \mathrm{C}$ without shaking. After incubation for $18 \mathrm{~h}, 0.1 \mathrm{ml}$ of the culture was inoculated into $\mathrm{I} 0 \mathrm{ml}$ fresh medium and incubated under the appropriate conditions for $3 \mathrm{~h}$; $0.1 \mathrm{ml}$ of this culture was used to inoculate $150 \mathrm{ml}$ culture medium and incubated under the same conditions. At the same time, a count of viable cells in the inoculum was made. Preliminary experiments indicated that the cultures were in the exponential phase of growth at this time.

Estimations of growth. Samples were withdrawn and growth was estimated by four methods:

I. Turbidity was measured at $640 \mathrm{~nm}$ in a $15 \mathrm{~mm}$ path using a Photovolt Lumetron photometer.

2. Viable counts using serial ro-fold dilutions were made in saline. Duplicate drops (Miles 
$\&$ Misra, 1938) of each dilution were made and those spots on Brain-Heart Infusion agar plates which contained 25 to 30 colonies were counted.

3. Cells separated by centrifuging ( $5000 \mathrm{~g}$ for $\mathrm{I} 5 \mathrm{~min}$ ) were dried to constant weight.

4. The weight of material precipitated by $5 \%(\mathrm{v} / \mathrm{v})$ cold perchloric acid was determined: samples were treated for $30 \mathrm{~min}$ at $4{ }^{\circ} \mathrm{C}$, and the precipitates, separated by centrifuging, were washed once with cold perchloric acid and dried to constant weight. Syncase medium itself gave no precipitate. When media containing bile salts were used, $10 \mathrm{ml}$ samples of cultures were dialysed against several changes of $0.85 \%$ saline before adding cold perchloric acid, since the acid precipitated sodium deoxycholate. Although some macromolecules might have been lost during dialysis, due to breakdown by the action of proteolytic and other degradative enzymes, this method gave higher values than method 3. Method 3 did not give consistently reliable results for cultures grown in media containing bile salts and was therefore not used in such cases.

Phase-contrast microscopy. Agar slides were prepared by layering $2 \mathrm{ml}$ Syncase agar (I.5\% agar in Syncase medium) on sterile microscope slides $(75 \times 25 \mathrm{~mm})$. A drop of culture was spread on the agar surface and viewed immediately using a phase-contrast microscope (Standard Universal Microscope; Carl Zeiss). The relative numbers of the different morphological types were estimated by counting at least six oil immersion fields in which the organisms were uniformly distributed.

Toxin tests. The supernatant fluid from centrifuged samples of cultures grown under various conditions was filtered through a $0.45 \mu \mathrm{m}$ membrane filter (Millipore) pre-moistened with fresh, sterile culture medium. The filtrates were collected in containers to which EDTA had been added to give a final concentration of $0.005 \%$, and were immediately cooled to $4{ }^{\circ} \mathrm{C}$ (Richardson, Evans \& Feeley, 1970). The filtrates obtained from cultures grown in media containing bile salts were dialysed against several changes of $0.85 \%$ saline at $4{ }^{\circ} \mathrm{C}$ for 24 to $30 \mathrm{~h}$. No bile salt was detected in the dialysed filtrates when tested by thin-layer chromatography.

The activities of the filtrates were assayed in two ways:

I. The passive haemagglutination inhibition test (PHI) was used to measure the toxinantigen in vivo. The reagents were prepared as described by Finkelstein \& Peterson (I970), and the test was performed as described by Callahan, Ryder \& Richardson (1971). Each sample was run in duplicate. Using this technique both active toxin and inactive antigen are estimated together.

2. The adult rabbit ileal loop assay was used to estimate active toxin in vivo. This assay was performed according to the method of Pierce \& Wallace (1972).

Verification of the presence of enterotoxin. Each sample which gave a positive result in the rabbit was tested to prove that enterotoxin was responsible for the intestinal response:

I. Neutralization with antitoxin (Kasai \& Burrows, I966). Horse anticholeragenoid (Finkelstein, 1970; N.I.H. lot no. I9) was used as antitoxin. The filtrates were incubated with an equal volume of a $\mathrm{I}: \mathrm{I} O 0$ dilution of antitoxin prepared in phosphate-buffered saline, $\mathrm{pH} 7.2$, at $37^{\circ} \mathrm{C}$ for $30 \mathrm{~min}$. Ligated rabbit intestinal loops were injected with $0.5 \mathrm{ml}$ of this mixture and with similar volumes of appropriate positive and negative control materials. The effect of the antitoxin on the volume/length ratio was determined $\mathrm{I} 4$ to $\mathrm{I} 6 \mathrm{~h}$ later when the animals were sacrificed.

2. Test for heat lability (Burrows \& Kaur, 1974). Samples of the filtrates which elicited a fluid response in the rabbit ileal loop assay were incubated at $56^{\circ} \mathrm{C}$ for $30 \mathrm{~min}$ and then tested for residual activity in rabbit intestinal loops.

Sodium deoxycholate treatment. Cells from $12 \mathrm{~h}$ cultures $(\mathrm{I} 00 \mathrm{ml})$ grown aerobically at 
$37^{\circ} \mathrm{C}$ in Syncase medium were washed once in Syncase medium and resuspended in $25 \mathrm{ml}$ Syncase medium containing $0.1 \%$ sodium deoxycholate. After incubating (aerobically at $37^{\circ} \mathrm{C}$ ) for $20 \mathrm{~min}$, with gentle agitation every few minutes, the suspension was filtered and collected in vials containing EDTA. The volume was made up to $100 \mathrm{ml}$ using Syncase medium and the samples were assayed for toxin.

Extraction of enterotoxin by EDTA treatment. Organisms from $100 \mathrm{ml}$ of a $\mathrm{I} 2 \mathrm{~h}$ culture were extracted with Tris/EDTA as described by Leive \& Shovlin (1968), dialysed and assayed for toxin.

Mechanical lysis of organisms. A dense suspension of the organisms obtained by resuspending the centrifuged, washed sediment of $100 \mathrm{ml}$ culture in $10 \mathrm{ml}$ medium was lysed using an X-Press (Biotec). Phase-contrast microscopy showed that approximately $90 \%$ lysis occurred. The lysate was reconstituted to $100 \mathrm{ml}$ in Syncase medium and centrifuged. The supernatant fluid was filtered and assayed for toxin.

\section{RESULTS}

\section{Growth and toxin production by $V$. cholerae $569 \mathrm{~B}$}

In Syncase medium incubated aerobically. Although there were no significant differences in turbidity, viable counts and dry weight of cold-acid-precipitated cultures at 30 and $37^{\circ} \mathrm{C}$, the dry weight of centrifuged culture sediment at $48 \mathrm{~h}$ was significantly less at $30^{\circ} \mathrm{C}$ than at $37^{\circ} \mathrm{C}$ (Fig. I). During early-exponential growth, pleomorphic cells were detected at $30^{\circ} \mathrm{C}$ (Fig. $2 a$ ) but not at $37^{\circ} \mathrm{C}$ (Fig. $2 b$ ). As reported previously (Richardson, 1969; Callahan et al., 197I), the toxin yield was greater at $30^{\circ} \mathrm{C}$ than at $37^{\circ} \mathrm{C}$.

In Syncase medium incubated anaerobically at $37^{\circ} \mathrm{C}$. There were no marked differences in growth and cellular morphology in stationary or shaken cultures incubated at 30 or $37^{\circ} \mathrm{C}$. Maximum turbidity was reached after $\mathrm{I} 2 \mathrm{~h}$ incubation (Fig. 3) but was less than that observed under aerobic conditions. Thereafter, turbidity, viable counts and dry weight decreased although the dry weight of cold-acid-precipitated cultures increased. Morphologically, vibrio-like forms predominated after $3 \mathrm{~h}$ although a few large rounded cells were seen (Fig. 4a). At $\mathrm{I} 2 \mathrm{~h}$, large round cells with vesicles, some of which appeared extruded, were most evident (Fig. $4 b$ ). By $33 \mathrm{~h}$ much debris and a few short rod-like or round cells were seen. Toxin yields were good at $\mathrm{I} 2$ and $33 \mathrm{~h}$ when cultures were incubated at $37^{\circ} \mathrm{C}$. When cultures were incubated anaerobically at $30^{\circ} \mathrm{C}$, culture turbidity and cellular morphology were similar to that obtained at $37^{\circ} \mathrm{C}$, but toxin was not detected until after $33 \mathrm{~h}$ incubation.

When the experiments were repeated using peptone water or V. cholerae BI307, essentially the same results were obtained.

In Syncase medium containing $0.1 \%$ sodium deoxycholate. The presence of the bile salt retarded increases in turbidity, viable counts and dry weight of cold-acid-precipitated cultures (Fig. 5) compared with the increases under similar incubation conditions without sodium deoxycholate. Morphologically the most striking features were the presence at 3 and $\mathrm{I} 2 \mathrm{~h}$ of at least $50 \%$ of cells with low refractive indices (ghosts), few pleomorphic forms and the remainder appearing to be normal. At $33 \mathrm{~h}$, the number of ghost cells had decreased and the cultures consisted of apparently normal vibrios. Toxin was detected in appreciable quantities after incubation for $33 \mathrm{~h}$ aerobically at $30^{\circ} \mathrm{C}$ (Fig. $5 a$ ), for $12 \mathrm{~h}$ aerobically at $37^{\circ} \mathrm{C} \mathrm{(Fig.} 5 \mathrm{~b}$ ) and for $33 \mathrm{~h}$ anaerobically at $37^{\circ} \mathrm{C}$ (Fig. $5 \mathrm{c}$ ).

Similar results were obtained when $V$. cholerae $\mathrm{BI} 307$ or peptone water containing $0 . \mathrm{I} \%$ sodium deoxycholate were used. 


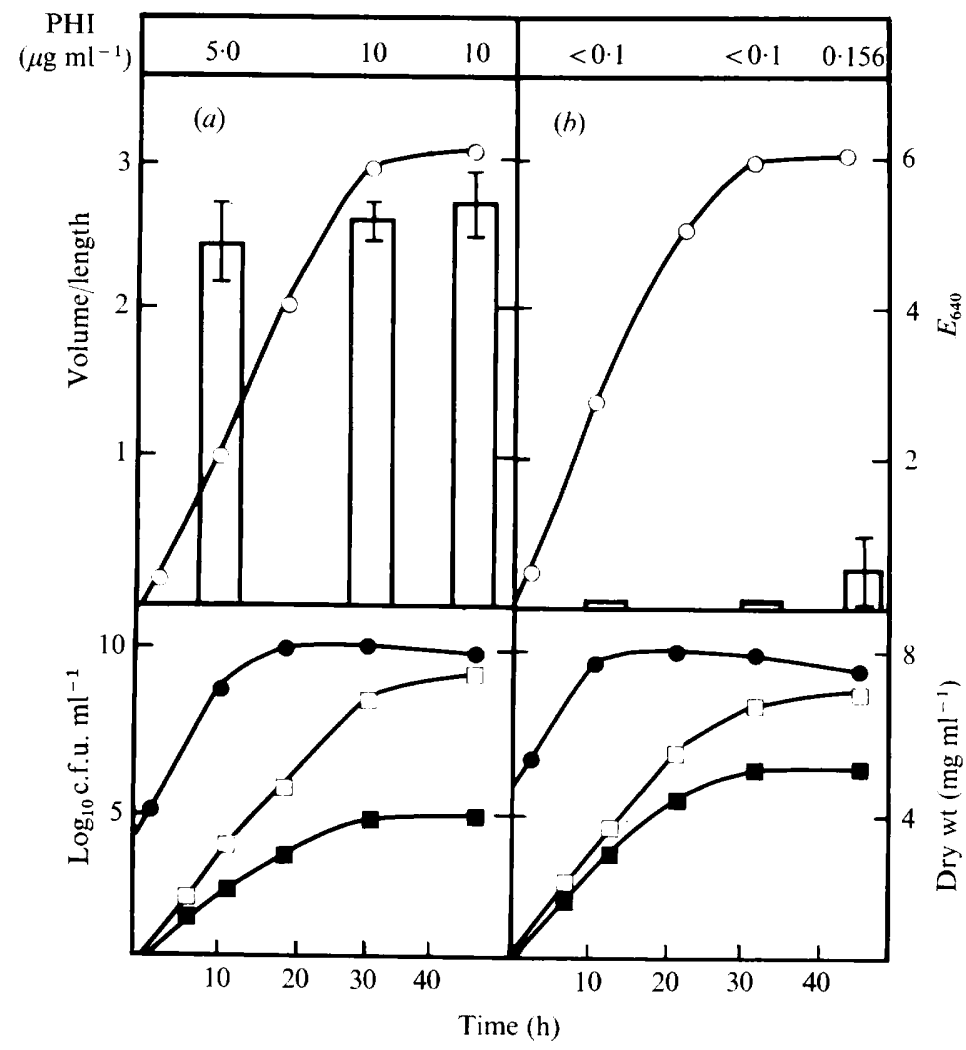

Fig. I. Growth and toxin production by $V$. cholerae $569 \mathrm{~B}$ grown aerobically in Syncase medium incubated with shaking at: (a) $30^{\circ} \mathrm{C}$; (b) $37^{\circ} \mathrm{C}$. Growth was measured as described in Methods. ,Viable counts $\left[\log _{10}(\right.$ colony-forming units $\left.) \mathrm{ml}^{-1}\right] ; O$, turbidity $\left(E_{640}\right) ; \mathbf{\square}$, dry weight of centrifuged culture sediments $\left(\mathrm{mg} \mathrm{ml}^{-1}\right) ; \square$, dry weight of cold-acid-precipitated cultures $\left(\mathrm{mg} \mathrm{ml}^{-1}\right)$. Culture filtrates were assayed for toxin-antigen $\left(\mu \mathrm{g} \mathrm{ml}^{-1}\right)$ by the passive haemagglutination inhibition test (PHI), and for biologically active toxin (volume/length response; bar) by the rabbit intestinal loop method. The volume/length ratios are the mean of six values obtained in different rabbits. The distribution indicates the standard error of the mean.
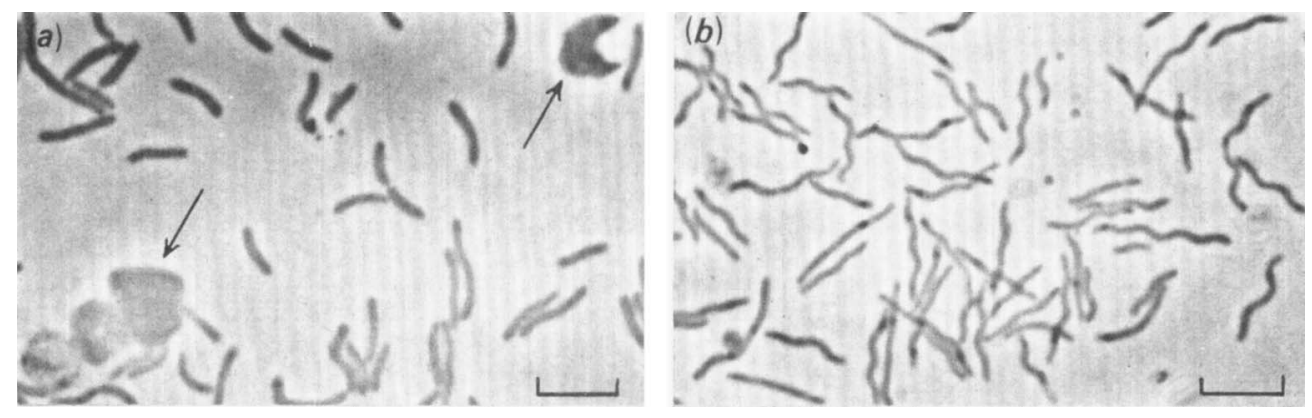

Fig. 2. Morphology of $V$. cholerae $569 \mathrm{~B}$ at $\mathrm{I} 2 \mathrm{~h}$ incubated aerobically at: $(a) 30^{\circ} \mathrm{C} ;(b) 37^{\circ} \mathrm{C}$. Arrows indicate large round cells with vesicles. Bar markers represent $2 \mu \mathrm{m}$. 


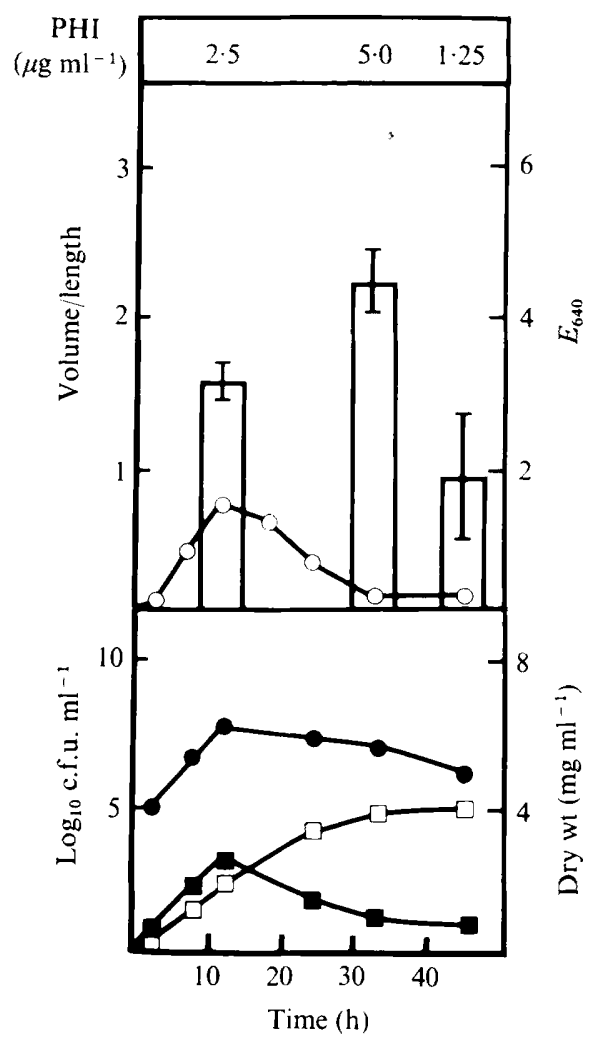

Fig. 3. Growth and toxin production by $V$. cholerae $569 \mathrm{~B}$ in Syncase medium, incubated anaerobically at $37^{\circ} \mathrm{C}$ without shaking. For symbols, see legend to Fig. I.
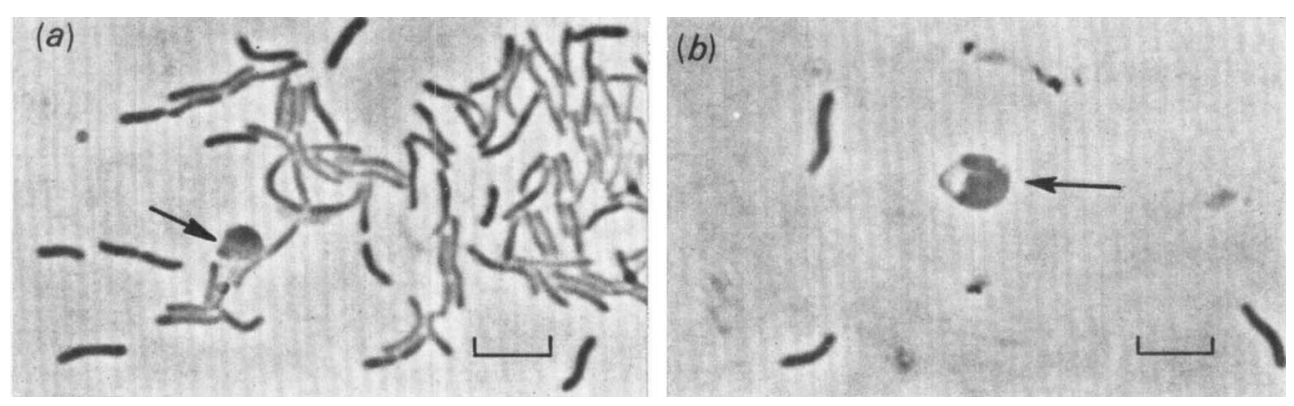

Fig. 4. Morphology of $V$. cholerae $569 \mathrm{~B}$ grown anaerobically at $37^{\circ} \mathrm{C}$ without shaking. (a) At $3 \mathrm{~h}$ : arrow indicates large round cell. $(b)$ At $12 \mathrm{~h}$ : arrow indicates large round cell with vesicle. Bar markers represent $2 \mu \mathrm{m}$.

Comparison of the amount of extracellular toxin with the intracellular and/or 'bound' toxin

The increased toxin yield in cultures incubated aerobically at $37^{\circ} \mathrm{C}$ in the presence of sodium deoxycholate could be due to (i) increased synthesis of toxin, (ii) release of intracellular toxin, as a result of increased membrane permeability or as a result of cell lysis, or 


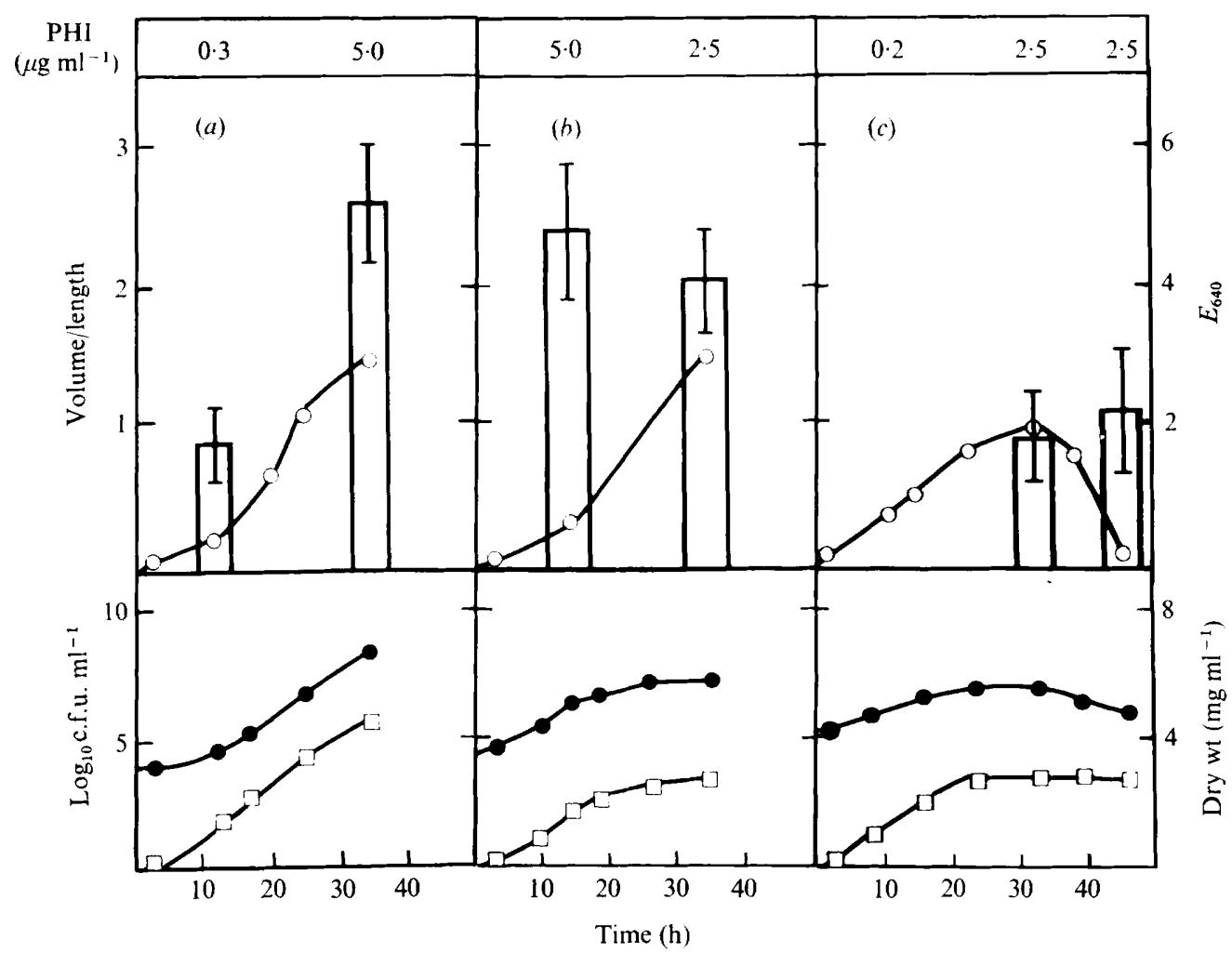

Fig. 5. Growth and toxin production by $V$. cholerae 569B grown in Syncase medium containing $0.1 \%$ sodium deoxycholate incubated: (a) aerobically at $30^{\circ} \mathrm{C}$ with shaking; $(b)$ aerobically at $37^{\circ} \mathrm{C}$ with shaking; $(c)$ anaerobically at $37^{\circ} \mathrm{C}$ without shaking. Three parameters of growth are shown: , viable counts $\left(\log _{10}\right.$ c.f.u. $\left.\mathrm{ml}^{-1}\right) ; \bigcirc$, turbidity $\left(E_{640}\right) ; \square$, dry weight of cold-acid-precipitated cultures $\left(\mathrm{mg} \mathrm{ml}^{-1}\right)$. Culture filtrates were assayed for toxin-antigen $\left(\mu \mathrm{g} \mathrm{ml}^{-1}\right)$ by the passive haemagglutination inhibition test (PHI), and for biologically active toxin (volume/length response; bar) by the rabbit intestinal loop method. The volume/length ratios are the mean of six values obtained from different rabbits. The distribution indicates the standard error of the mean.

(iii) release of toxin from a 'bound' form. When $0 \cdot 1 \%$ sodium deoxycholate was added to organisms grown aerobically at $37^{\circ} \mathrm{C}$, the toxin yield in $20 \mathrm{~min}$ was $5.0 \mu \mathrm{g} \mathrm{ml}^{-1}(2 \cdot 3 \mathrm{~V} / \mathrm{l}$ response) whereas the toxin yield was only $0.2 \mu \mathrm{g} \mathrm{ml}^{-1}(<0.5 \mathrm{~V} / \mathrm{l}$ response) when Syncase medium containing no sodium deoxycholate was added. The free intracellular toxin released by mechanical lysis was only $0.3 \mu \mathrm{g} \mathrm{ml}^{-1}$ ( $<0.5 \mathrm{~V} / \mathrm{l}$ response). When $0 . \mathrm{I} \%$ sodium deoxycholate was added to cell lysates prepared using the X-Press, the toxin yield was $2.5 \mu \mathrm{g} \mathrm{ml}^{-1}$ $(3 \cdot 0 \mathrm{~V} / \mathrm{l}$ response).

When organisms grown aerobically at $37^{\circ} \mathrm{C}$ were treated with Tris/EDTA the toxin yield varied from 0.5 to $2.0 \mu \mathrm{g} \mathrm{ml}^{-1}$. This toxin-antigen measured by the PHI assay did not elicit a fluid response in the rabbit intestinal loop. Adding Tris/EDTA to crude cholera toxin (freeze-dried culture filtrate; Wyeth Laboratories, Philadelphia, U.S.A.; lot no. $4493 \mathrm{G}$ ) did not affect the rabbit intestinal fluid response.

When $0.1 \%$ sodium deoxycholate was added to crude cholera toxin, incubated for $\mathrm{I} h$ at $37^{\circ} \mathrm{C}$ and tested in rabbit intestinal loops and by the PHI assay, the results obtained were not significantly different from those obtained with toxin alone. 


\section{Effect of sodium glycocholate and Brij-38 on the growth and toxin production by $V$. cholerae $569 \mathrm{~B}$}

The addition of $0.1 \%$ sodium glycocholate to Syncase medium did not alter growth and toxin production in cultures incubated aerobically at $30^{\circ} \mathrm{C}$ and anaerobically at $37^{\circ} \mathrm{C}$. Under aerobic conditions at $37^{\circ} \mathrm{C}$, the turbidity of the culture was similar to that obtained in medium with no sodium glycocholate but the toxin yield was increased to $2.5 \mu \mathrm{g} \mathrm{ml}^{-1}$ (2.0 $\mathrm{V} / \mathrm{l}$ response) at $\mathrm{I} 2 \mathrm{~h}$ and $2 \cdot 5 \mu \mathrm{g} \mathrm{ml}^{-1}(2 \cdot 2 \mathrm{~V} / \mathrm{l}$ response) at $33 \mathrm{~h}$.

Growth and toxin production in cultures incubated aerobically at $30^{\circ} \mathrm{C}$ and anaerobically at $37^{\circ} \mathrm{C}$ in medium containing $0.1 \%$ Brij-38 was similar to that obtained in medium containing sodium deoxycholate. Under aerobic conditions at $37^{\circ} \mathrm{C}$ the growth was similar to that obtained in medium containing sodium deoxycholate, but the toxin yield was decreased to $0.63 \mu \mathrm{g} \mathrm{ml}^{-1}$ ( $\mathrm{I} \cdot 7 \mathrm{~V} / \mathrm{l}$ response) at $\mathrm{I} 2 \mathrm{~h}$ and $0.63 \mu \mathrm{g} \mathrm{ml}^{-1}$ (3.9 V/l response) at $33 \mathrm{~h}$.

\section{DISCUSSION}

The toxin yield in $V$. cholerae cultures depends on the environmental conditions in which they are grown. The environmental factors studied by other investigators indicate that aerobic incubation at $30^{\circ} \mathrm{C}$ yields the largest amounts of toxin (Kusama \& Craig, I970; Richardson, 1969). These incubation conditions are not optimal for growth since we found large numbers of pleomorphic cells, similar to those noted by Kennedy \& Richardson (1969), in the exponential growth phase of such cultures. Under aerobic conditions, although the turbidity and viable counts at $37^{\circ} \mathrm{C}$ were similar to those obtained at $30^{\circ} \mathrm{C}$, all the organisms had a 'normal' vibrio shape in the exponential growth phase. Therefore, we confirm Pollitzer's finding (1959) that aerobic incubation at $37^{\circ} \mathrm{C}$ is optimal for growth, but find the toxin yield is then minimal confirming the work of Craig (I966), Richardson (I969) and Gallut \& Jude (1955). In cultures incubated anaerobically at 30 or $37^{\circ} \mathrm{C}$, the cellular yield was lower and the organisms were pleomorphic but large amounts of toxin were produced. Therefore, we assume that sub-optimal growth conditions result in pleomorphic cells and a large toxin yield.

Sodium deoxycholate, a surfactant, was used to determine the effect of bile salts on $V$. cholerae. Its ability to inhibit the aerobic growth of $V$. cholerae is interesting since aerobic Gram-negative bacteria are resistant to the inhibitory action of bile salts (Binder, Filburn \& Floch, 1975). Sodium deoxycholate did not affect the toxin yield per mg dry wt of culture under sub-optimal growth conditions, i.e. aerobically at $30^{\circ} \mathrm{C}$ or anaerobically at $37^{\circ} \mathrm{C}$, whereas the toxin yield was increased in cultures incubated aerobically at $37^{\circ} \mathrm{C}$ from $0 . \mathrm{I}$ to $5^{\circ} \circ \mu \mathrm{g} \mathrm{ml}^{-1}$, which was equal to or greater than the toxin yield under sub-optimal conditions. Other surfactants such as sodium glycocholate, the most common conjugated bile salt of man, and the non-ionic detergent Brij-38 also increased toxin yield in aerobic cultures at $37^{\circ} \mathrm{C}$. Sodium glycocholate, unlike sodium deoxycholate, did not inhibit the growth of $V$. cholerae. Floch et al. (1972) obtained similar results using other intestinal organisms.

The ability of sodium deoxycholate to increase toxin yield in cultures grown aerobically at $37^{\circ} \mathrm{C}$ was not due to activation of 'free' toxin molecules since it did not increase the activity of crude cholera toxin. Nor was it due to release of intracellular toxin since mechanical lysis of organisms grown aerobically at $37^{\circ} \mathrm{C}$ yielded little toxin. However, treatment of the mechanically lysed cells or of whole cells grown aerobically at $37^{\circ} \mathrm{C}$ with $0.1 \%$ sodium deoxycholate released large amounts of toxin, indicating that the toxin was bound to some component of the cell. Tris/EDTA, which releases periplasmic enzymes from 
Gram-negative bacteria (Leive \& Shovlin, 1968), did not release active toxin but did release biologically inactive antigen which cross-reacted with the toxin in the PHI test. This may be of some practical interest since the non-toxic antigen is likely to be choleragenoid, a naturally occurring non-toxic antigen (Finkelstein, Peterson \& LoSpalluto, 1971).

Our results can account for the physiology of enterotoxin secretion. The organism produces toxin under a variety of cultural conditions, and this toxin is bound, probably to a lipid-containing component of the cell. If the environmental conditions result in abnormal morphological forms - an outward manifestation of altered structure and function of the cell envelope - the toxin escapes to the environment. When the morphology is 'normal' the toxin is bound and can only be released when the cell envelope is ruptured and the toxin is released from the lipid (by using detergents such as bile salts). This may be similar to the results reported by Evans, Evans \& Gorbach (I974) on the release of enterotoxin from E. coli by treatment with polymyxin B.

Our experiments were directed to learning more about cholera enterotoxin production under conditions that resembled those found in the human intestine rather than under the highly aerobic conditions at $30^{\circ} \mathrm{C}$ used in the conventional in vitro methods. It has been shown that cholera vibrios can produce extracellular toxin when grown at $37^{\circ} \mathrm{C}$ under anaerobic conditions or aerobically at $37^{\circ} \mathrm{C}$ in the presence of bile salts, especially sodium deoxycholate. The experiments indicate that one does not need the large cell yield obtained from aerobic cultures to get an equivalent quantity of toxin from anaerobic cultures. To explain how sodium deoxycholate becomes involved in cholera pathogenesis, one needs only to recall that this is formed by the action of intestinal bacteria on primary bile acids, and the upper small bowels of cholera patients have been found to be colonized by a number of bacteria capable of effecting this chemical change (Gorbach et al., 1970).

This research was supported by the National Institutes of Health, Bethesda, Maryland, U.S.A., grant no. NIAID-AI I II96.

We wish to thank Drs Jussi J. Saukkonen and Russell W. Schaedler for suggestions and review of this study.

\section{REFERENCES}

ARANKI, A. \& Freter, R. (1972). Use of anaerobic glove boxes for the cultivation of strictly anaerobic bacteria. American Journal of Clinical Nutrition 25, $1329-1334$.

BANERJEe, D. N. (1939). Culture du Vibrion cholerique anaerobie, les variations de son pH et son pouvoir toxique. Comptes rendus des séances de la Société de biologie r3o, 32-34.

Binder, H. J., Filburn, B. \& Floch, M. (1975). Bile and inhibition of intestinal anaerobic organisms. American Journal of Clinical Nutrition 58, I19-1 25.

Burrows, W. \& Kaur, J. (1974). Cholera toxins. In Cholera, pp. I43-I67. Edited by D. Barua and W. Burrows. Philadelphia: W. B. Saunder.

Callahan, L. T., Ryder, R. C. \& Richardoson, S. H. (I97I). Biochemistry of Vibrio cholerae virulence. II. Skin permeability factor/cholera enterotoxin production in a chemically defined medium. Infection and Immunity $4,6 \mathrm{I} \mathrm{I}-6 \mathrm{I} 8$.

Craig, J. P. (I966). Preparation of the vascular permeability factor from Vibrio cholerae. Journal of Bacterio$\log y$ 95, 793-795.

De, S. N., Ghosh, M. L. \& Chandra, J. (1962). Further observations on cholera enterotoxin. Transactions of the Royal Society of Tropical Medicine and Hygiene 56, 24I-245.

Evans, D. J., Evans, D. G. \& Gorbach, S. L. (1974). Polymyxin B induced release of low molecular weight heat-labile enterotoxin from Escherichia coli. Infection and Immunity 10, I010-1017.

Finkelstein, R. A. (1970). Monospecific equine antiserum against cholera enterotoxin. Infection and Immunity 2, 69I-697.

Finkelstein, R. A., Atthasampunna, P., Chulasamaya, P. \& Charunmethee, P. (i966). Pathogenesis of experimental cholera: biological activities of purified procholeragen A. Journal of Immunology 96, 440449. 
Finkelstein, R. A., Peterson J. W. \& LoSpalluto, J. J. (I97I). Conversion of cholera exo-enterotoxin (choleragen) to natural toxoid (choleragenoid). Journal of Immunology 106, 868.

Finkelstein, R. A. \& Peterson, J. W. (r970). In vitro detection of antibody to cholera enterotoxin in cholera patients and laboratory animals. Infection and Immunity I, 2I-29.

Floch, M. H., Binder, H. J., Filburn, B. \& Gershengoran, W. (I972). The effect of bile acids on intestinal microflora. American Journal of Clinical Nutrition 55, 1418-I426.

FreTER, R. (1969). Studies of the mechanism of action of intestinal antibody in experimental cholera. Texas Reports on Biology and Medicine 27, Suppl. I, 299-316.

FRETER, R. (1972). Parameters affecting the association of vibrios with the intestinal surface - experimental cholera. Infection and Immunity 6, I34-r41.

Gallut, J. \& Jude, A. (I955). Contributions a l'étude de la virulence et du pouvoir toxigène du Vibrion cholerique. II. Influence de la temperature d'incubation sur le pouvoir toxigene in vitro de Vibrio cholerae (Ogawa). Annales de l'Institut Pasteur 88, 282-288.

Gorbach, S. L., Banwell, J. G., Jacobs, B., Chatterjee, B. D., Mitra, R., Brigham, K. L. \& Neogy, K. N. (1970). Intestinal microflora in Asiatic cholera. II. The small bowel. Journal of Infectious Diseases I21, 38-45.

HIRSCH, J. vON (1926). Die anaerobe Züchtung des Vibrio cholerae. Klinische Wochenschrift 5, ro89.

HofmanN, A. F. (1962). Thin-layer adsorption chromatography of free and conjugated bile acids on silicic acid. Journal of Lipid Research $3,127-128$.

Kasai, G. J. \& Burrows, W. (I966). The titration of cholera toxin and antitoxin in the rabbit ileal loop. Journal of Infectious Diseases I16, 606-6I4.

KENNEDY, J. R. \& RICHARDSON, S. H. (1969). Fine structure of Vibrio cholerae during toxin production. Journal of Bacteriology I00, I393-140I.

Kusama, H. \& Craig, J. P. (I970). Production of biologically active substances by two strains of Vibrio cholerae. Infection and Immunity $\mathbf{r}, 80-87$.

Leive, L. \& Shovlın, V. K. (I968). Physical, chemical and immunological properties of lipopolysaccharide released from Escherichia coli by ethylenediaminetetraacetate. Journal of Biological Chemistry 543, $6384-6391$.

Linton, R. W., Mitra, B. N. \& Seal, S. C. (1936). Further notes on the cholera and cholera-like vibrios. Indian Journal of Medical Research 23, 60I-607.

Mrles, A. A., \& MrsRa, S. S. (1938). The estimation of the bactericidal properties of blood. Journal of Hygiene (Cambridge) 38, 732-749.

Norman, A. \& GrubB, R. (I955). Hydrolysis of conjugated bile acids by clostridia and enterococci. Acta pathologica et microbiologica scandinavica 36, 537-547.

Pierce, N. F. \& Wallace, C. K. (I972). Stimulation of jejunal secretion by a crude Escherichia coli enterotoxin. Gastroenterology $\mathbf{6 3}, 439-448$.

POLlitzer, R. (1959). Cholera. World Health Organization monograph series no. 43. Geneva, Switzerland: WHO.

RICHARDSON, S. H. (1969). Factors inffuencing in vitro skin permeability factor production by Vibrio cholerae. Journal of Bacteriology 100, 27-34.

Richardson, S. H., Evans, D. G. \& Feeley, J. C. (1970). Biochemistry of Vibrio cholerae virulence. I. Purification and biochemical properties of PF/cholera enterotoxin. Infection and Immunity $\mathbf{1}, 546-$ 554 . 